\title{
Talin is required for integrin-mediated platelet function in hemostasis and thrombosis
}

\author{
Brian G. Petrich, ${ }^{1}$ Patrizia Marchese, ${ }^{2}$ Zaverio M. Ruggeri, ${ }^{2}$ Saskia Spiess, ${ }^{1}$ \\ Rachel A.M. Weichert, ${ }^{1}$ Feng Ye, ${ }^{1}$ Ralph Tiedt,${ }^{3}$ Radek C. Skoda, ${ }^{3}$ \\ Susan J. Monkley, ${ }^{4}$ David R. Critchley, ${ }^{4}$ and Mark H. Ginsberg ${ }^{1}$ \\ 1Department of Medicine, University of California, San Diego, La Jolla, CA 92093 \\ 2Department of Molecular and Experimental Medicine, The Scripps Research Institute, La Jolla, CA 92037 \\ ${ }^{3}$ Department of Experimental Hematology, University Hospital Basel, 4031 Basel, Switzerland \\ ${ }^{4}$ Department of Biochemistry, Henry Wellcome Building, University of Leicester, Leicester LE1 9HN, UK
}

\begin{abstract}
Integrins are critical for hemostasis and thrombosis because they mediate both platelet adhesion and aggregation. Talin is an integrin-binding cytoplasmic adaptor that is a central organizer of focal adhesions, and loss of talin phenocopies integrin deletion in Drosophila. Here, we have examined the role of talin in mammalian integrin function in vivo by selectively disrupting the talin 1 gene in mouse platelet precursor megakaryocytes. Talin null megakaryocytes produced circulating platelets that exhibited normal morphology yet manifested profoundly impaired hemostatic function. Specifically, platelet-specific deletion of talin 1 led to spontaneous hemorrhage and pathological bleeding. Ex vivo and in vitro studies revealed that loss of talin 1 resulted in dramatically impaired integrin $\alpha$ llb $\beta 3-$ mediated platelet aggregation and $\boldsymbol{\beta} 1$ integrin-mediated platelet adhesion. Furthermore, loss of talin 1 strongly inhibited the activation of platelet $\beta 1$ and $\beta 3$ integrins in response to platelet agonists. These data establish that platelet talin plays a crucial role in hemostasis and provide the first proof that talin is required for the activation and function of mammalian $\alpha 2 \beta 1$ and $\alpha$ llb $\beta 3$ integrins in vivo.
\end{abstract}

CORRESPONDENCE

Mark H. Ginsberg:

mhginsberg@ucsd.edu
Thrombosis and hemostasis depend on platelet function. Upon disruption of vascular integrity, platelets adhere to sites of injury and aggregate, thereby preventing excessive bleeding (1). Stable platelet adhesion to the injured blood vessel and subsequent aggregation in turn depend on integrin adhesion receptors. This point is well illustrated in patients with genetic defects in integrin subunits $\alpha \mathrm{IIb}$ or $\beta 3$ that cause the bleeding disorder Glanzmann thrombasthenia due primarily to defective platelet aggregation or in animals lacking all $(\alpha 2 \beta 1, \alpha 5 \beta 1$, and $\alpha 6 \beta 1)$ (2) or certain ( $\alpha 2 \beta 1$ ) (3) platelet $\beta 1$ integrins that manifest milder bleeding defects due to reduced platelet adhesion to vascular surfaces $(3,4)$.

The ability of platelets to increase integrin affinity (operationally defined as integrin activation) is critical for normal platelet function. Circulating platelets are usually in a resting state. Upon stimulation through agonist receptors, such as

$\overline{\text { The online version of this article contains supplemental material. }}$ those for ADP, collagen, or thrombin, signaling events within the platelet lead to complex biological effects including activation of $\beta 1$ and $\beta 3$ integrins (5). Activated $\alpha \operatorname{IIb} \beta 3$ then binds plasma proteins such as fibrinogen, leading to platelet aggregation, whereas activation of $\beta 1$ integrins leads to adhesion of platelets to vessel wall components such as collagen $(1,5)$. The molecular events that link agonist receptors to integrin activation are incompletely understood; however, experiments in cultured cells have indicated that this signaling results in increased association of the cytoplasmic protein talin with the integrin $\beta$ subunit cytoplasmic domain, inducing an increase in integrin affinity via a long-range allosteric change in the integrin's conformation (6). The requirement of talin for integrin activation has been examined in vitro; however, its role in vivo remains to be determined.

Talin is a $270-\mathrm{kD}$ protein composed of a $50-\mathrm{kD}$ head domain and a $220-\mathrm{kD}$ rod domain. It was identified in platelets where it comprises 
$3-8 \%$ of total platelet protein (7). The head domain contains binding sites for $\beta 1 \mathrm{~A}, \beta 1 \mathrm{D}, \beta 2, \beta 3, \beta 5$, and $\beta 7$ (8) integrin subunits and for another membrane protein, layilin (9). The rod domain contains binding sites for vinculin and F-actin. Thus, talin serves as a critical link between integrins and the actin cytoskeleton (10). Furthermore, in invertebrates, talin is necessary for formation of the integrin-associated cytoplasmic protein complex that includes proteins such as paxillin, vinculin, integrin-linked kinase, PINCH, and parvin (11). Lack of talin phenocopies lack of integrins in Drosophila, probably due to disrupted linkage to the actin cytoskeleton $(11,12)$. There are two mammalian talin isoforms encoded by distinct genes: talin1 is expressed ubiquitously, and talin2 is highly expressed in brain and striated muscle (13). In mice, global deletion of talin 1 results in embryonic lethality between embryonic days 8.5 and 9.5 due to defects in cell migration before and during gastrulation (14). Thus, based on studies in vitro and in invertebrates, talin is essential for the function of certain integrins and for integrin activation. To examine the role of talin in integrin function in vivo, we selectively deleted talin 1 in platelets and megakaryocytes in mice and found that platelet talin1 is essential for hemostasis because it is required for the function and activation of platelet $\alpha 2 \beta 1$ and $\alpha \operatorname{IIb} \beta 3$ integrins.

\section{RESULTS AND DISCUSSION}

\section{Platelet-specific deletion of talin 1}

Global genetic deletion of talin1 in mice is lethal by embryonic day 9 (14). To circumvent this early embryonic lethality, we deleted talin1 specifically in platelet precursor megakaryocytes

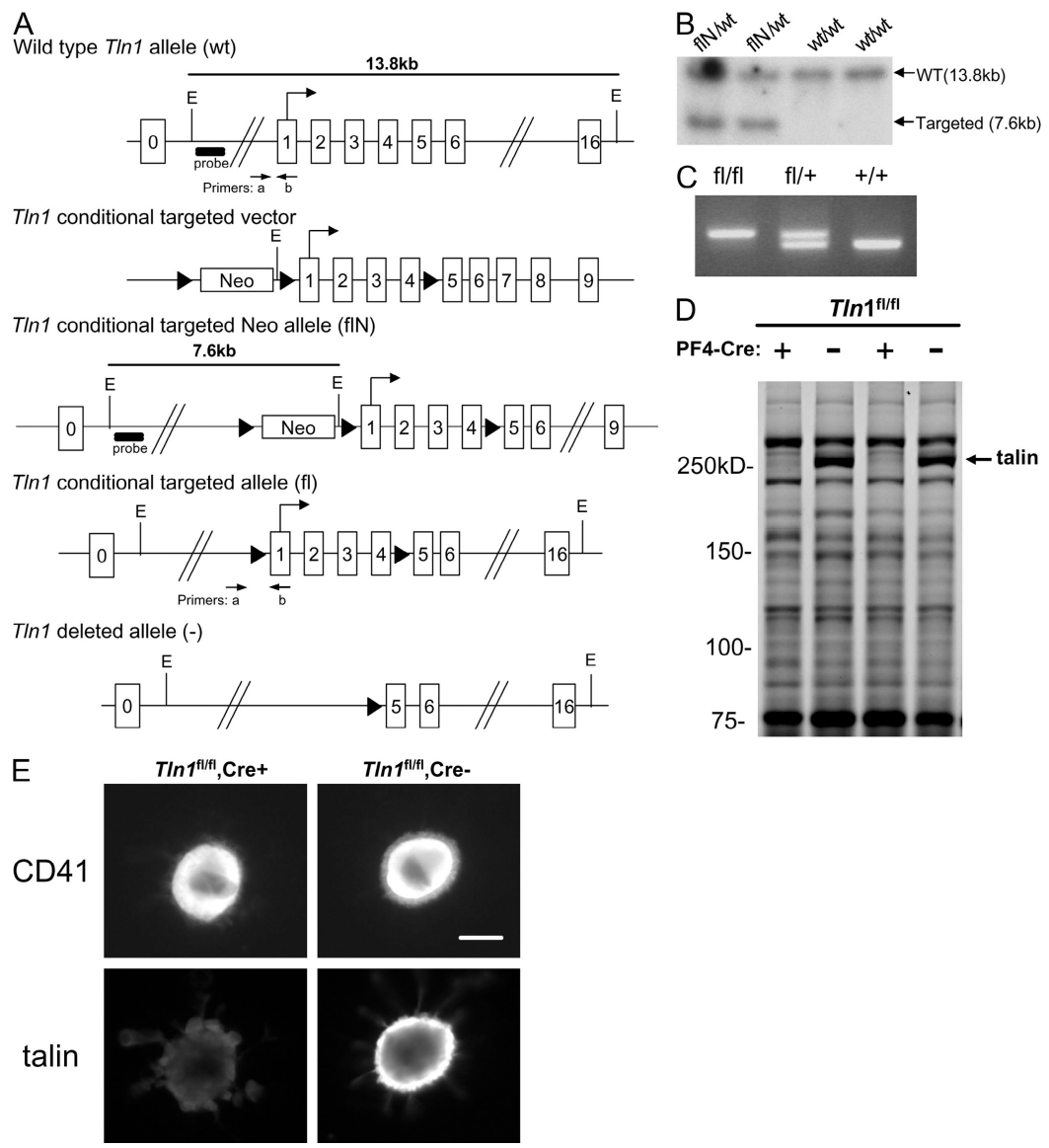

Figure 1. Deletion of talin1 in platelets and megakaryocytes. (A) Scheme of the targeting strategy. Homologous recombination of the TIn 1 conditional targeting vector into the TIn1 gene of embryonic stem cells introduced a loxP site (triangle) downstream of exon 4 and a floxed Neo cassette upstream of exon 1 to generate the targeted Neo allele (fIN). Partial Cre-mediated recombination in vivo was used to delete only the floxed Neo cassette leaving floxed exons 1-4 (conditional allele, fl). In cells expressing both the T/n1 conditional allele and PF4-Cre, Cre recombinase-mediated recombination will result in deletion of coding exons 1-4, generating the TIn 1-deleted allele (2). E, EcoRl; probe, external probe for Southern analysis. Primers used for genotyping mice are indicated. (B) Demonstration of homologous recombination in embryonic stem cells by Southern blotting. Genomic DNA from embryonic stem clones was digested with EcoRI and probed with an external probe shown in A. The wild-type allele gives rise to a 13.8-kb band (wt/wt), whereas the targeted allele gives rise to a 7.6-kb band due to introduction of an internal EcoRI site (fIN/wt). (C) PCR genotyping of mice possessing the conditional allele. Genomic DNA isolated from ear biopsies of $T \ln 7^{\mathrm{fl} / \mathrm{fl}}, T \ln 7^{\mathrm{fl} /+}$, and $T \ln 7^{\mathrm{fl} /+}$ mice was analyzed by PCR using the primer pair shown in A. (D) Coomassie blue-stained SDS-PAGE gel of platelet lysates

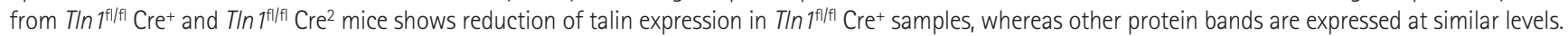
(E) Immunostaining of freshly isolated bone marrow samples showing reduced talin expression in CD $41^{+}$megakaryocytes from $\mathrm{Tln} 7^{f / f l} \mathrm{Cre}+\mathrm{mice}$. Bar, $20 \mathrm{~mm}$. 
by crossing mice harboring a floxed talin1 allele (Tln1) (Fig. $1 \mathrm{~A})$ with platelet factor 4-Cre (PF4-Cre) mice that express Cre recombinase selectively in platelets and megakaryocytes (15). Mice homozygous for the floxed $T \ln 1$ allele and positive for the PF4-Cre transgene ( $\left.\ln 1^{\mathrm{f} / \mathrm{fl}} \mathrm{Cre}^{+}\right)$had slightly reduced platelet counts compared with $T \ln 1^{\mathrm{fl} / \mathrm{fl}} \mathrm{Cre}^{-}$littermates (Table S1, available at http://www.jem.org/cgi/content/full/ jem.20071800/DC1) that were still in the normal range (16). SDS-PAGE analysis of platelet lysates revealed a selective loss in the band corresponding to talin in $T \ln 1^{\mathrm{f} / \mathrm{fl}} \mathrm{Cre}^{+}$platelets (Fig. 1 D). In addition, loss of talin was observed by immunofluorescence in $\mathrm{CD}_{4} 1^{+}$megakaryocytes from the bone marrow of $T \ln 1^{\mathrm{f} / \mathrm{fl}} \mathrm{Cre}^{+}$mice (Fig. $1 \mathrm{E}$ ). Deletion of talin in $T \ln 1^{\mathrm{A} / \mathrm{fl}}$ $\mathrm{Cre}^{+}$mice was only detectable in platelets and megakaryocytes as $\mathrm{CD} 41^{-}$bone marrow cells from $T \ln 1^{\mathrm{f} / \mathrm{fl}} \mathrm{Cre}^{+}$mice showed similar low levels of talin immunofluorescence as that from $T \ln 1^{\mathrm{f} / \mathrm{fl}} \mathrm{Cre}^{-}$mice (not depicted), consistent with PF4-Cremediated recombination being selective for the megakaryocytic lineage as reported previously (15).

These results show that terminal megakaryocyte development and platelet formation do not require talin. Large megakaryocytes from $T \ln 1^{\mathrm{A} / \mathrm{fl}} \mathrm{Cre}^{+}$mice were devoid of talin as judged by staining of bone marrow cells with the $8 \mathrm{~d} 4$ monoclonal antibody. Importantly, we targeted the talin 1 allele and not talin2, an isoform that is very similar to talin1 (13). Nevertheless, hematopoietic cells express little talin2 (13). Furthermore, the $8 \mathrm{~d} 4$ antibody reacts with both talin isoforms, and thus the absence of $8 \mathrm{~d} 4$ staining of megakaryocytes from $T \ln 1^{\mathrm{f} / \mathrm{fl}} \mathrm{Cre}^{+}$ mice confirms the elimination of talin expression in mature megakaryocytes. Previous work establishes that the PF4-cre mice we used express Cre specifically in megakaryocytes, including large megakaryocytes (15), and we observed that talin was still present in other cells of the hematopoietic lineage in the $T \ln 1^{\mathrm{f} / \mathrm{fl}} \mathrm{Cre}^{+}$mice. In spite of elimination of most of the talin, we observed abundant megakaryocytes in the bone marrow of the platelet talin1-deficient mice. Talin-deficient platelets were present at normal abundance, indicating that talin is not required for the formation of platelets from megakaryocytes. It is noteworthy that there was a slight reduction in platelet count in $T \ln 1^{\mathrm{f} / \mathrm{fl}} \mathrm{Cre}^{+}$mice relative to $T \ln 1^{\mathrm{fl} / \mathrm{fl}} \mathrm{Cre}^{-}$littermates. This reduction was not due to the presence of the PF4-Cre transgene in the absence of the floxed $T \ln 1$ allele because $T \ln 1^{\mathrm{f} /+} \mathrm{Cre}^{+}$mice had platelet counts similar to that of $T \ln 1^{\mathrm{f} / \mathrm{fl}}$ $\mathrm{Cre}^{-}$mice $\left(755 \pm 24\right.$ vs. $777 \pm 74, \times 10^{9}$ platelets $/ \mathrm{ml} \pm \mathrm{SEM}$, $T \ln 1^{\mathrm{f} / \mathrm{fl}} \mathrm{Cre}^{-}$vs. $\left.T \ln 1^{\mathrm{fl} /+} \mathrm{Cre}^{+}\right)$. Hence, it will be of interest in future work to examine the response of these animals to challenges to megakaryocytopoiesis.

\section{Bleeding diathesis in platelet talin-deficient mice}

Despite normal platelet counts in adult $T \ln 1^{\mathrm{f} / \mathrm{fl}} \mathrm{Cre}^{+}$mice (Table S1), these mice showed dramatically impaired hemostasis. In a tail bleeding assay, $T \ln 1^{\mathrm{f} / \mathrm{fl}} \mathrm{Cre}^{+}$mice bled continuously for the 10-min duration of the assay, whereas $T \ln 1^{\mathrm{f} / \mathrm{fl}}$ $\mathrm{Cre}^{-}$mice stopped bleeding an average of $4.6 \mathrm{~min}$ after tail resection (Fig. 2 A). Platelet talin deficiency was also associated with spontaneous bleeding. Lethal spontaneous internal hemorrhage, most often localized to the abdominal cavity, was observed in $8 \%$ of $1-2-\mathrm{d}$-old $T \ln 1^{\mathrm{f} / \mathrm{fl}} \mathrm{Cre}^{+}$mice (Fig. $2 \mathrm{~B}$ ). By 3 wk of age, $45 \%$ fewer $T \ln 1^{\mathrm{f} / \mathrm{fl}} \mathrm{Cre}^{+}$than $T \ln 1^{\mathrm{f} / \mathrm{fl}} \mathrm{Cre}^{-}$ mice were alive. In addition, 12 out of $76 T \ln 1^{\mathrm{fl} / \mathrm{fl}} \mathrm{Cre}^{+}$mice were found dead between 3 and 9 wk of age compared with 3 out of $139 T \ln 1^{\mathrm{f} / \mathrm{fl}} \mathrm{Cre}^{-}$mice (Fig. 2 B). $T \ln 1^{\mathrm{f} / \mathrm{fl}} \mathrm{Cre}^{+}$mice that survived to $8 \mathrm{wk}$ of age had a $95 \%$ incidence of gastrointestinal bleeding compared with $7 \%$ of $T \ln 1^{\mathrm{A} / \mathrm{fl}} \mathrm{Cre}^{-}$littermates as judged by an assay for fecal blood (Fig. 2 C). Gastrointestinal bleeding in $T \ln 1^{\mathrm{f} / \mathrm{fl}} \mathrm{Cre}^{+}$mice was associated with profound anemia as manifested by significantly reduced

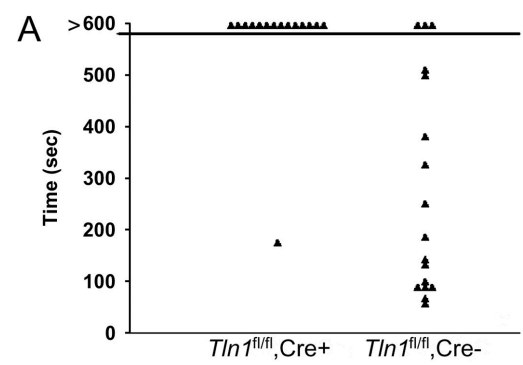

B

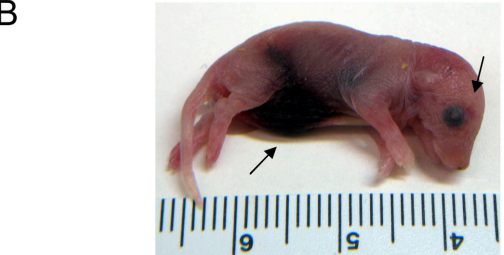

\begin{tabular}{|l|c|c|c|}
\hline & $T \ln 1^{\mathrm{fl} / \mathrm{fl}}, \mathrm{Cre}+$ & $T \ln 1^{\text {f//fl }}$, Cre- & $P$ Value \\
\hline mice alive at 3 weeks of age & 76 & 139 & $<0.002$ \\
\hline Found dead (3-9 weeks of age) & $15.8 \%(12 / 76)$ & $2.2 \%(3 / 139)$ & $<0.0005$ \\
\hline
\end{tabular}
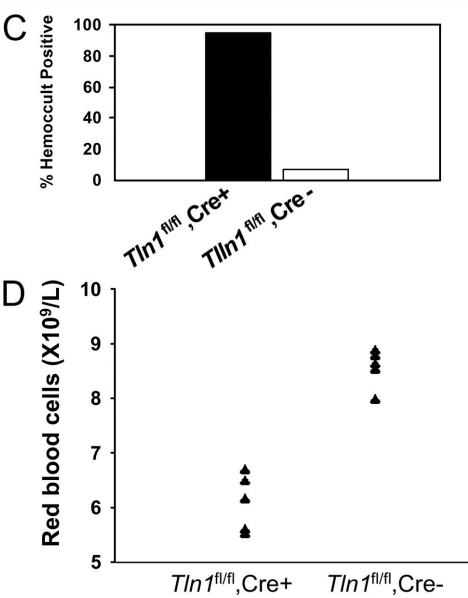

Figure 2. Reduced survival and perinatal hemorrhage in $\operatorname{Tln} 1^{\mathrm{fl} / \mathrm{fl}}$ $\mathrm{Cre}^{+}$mice. (A) $\mathrm{Tln}^{f^{f l / f l}} \mathrm{Cre}^{+}$mice have prolonged bleeding times in a tail bleeding assay. Time to cessation of bleeding after tail resection was recorded for up to $10 \mathrm{~min}$, at which time bleeding was stopped by cauterization. (B) Example of 1-d-old $T / n 7^{f / f l} \mathrm{Cre}^{+}$pup found dead with visible internal hemorrhage (arrows). Table showing reduced survival of $T / n 7^{f|f| f l}$ $\mathrm{Cre}^{+}$mice. The number of animals obtained from $\mathrm{T} / n 7^{\mathrm{fl} / \mathrm{fl}} \mathrm{Cre}^{2} \times \operatorname{Tln} 7^{\mathrm{fl} / \mathrm{fl}}$ $\mathrm{Cre}^{+}$breeding at $3 \mathrm{wk}$ of age is shown. (C) Incidence of fecal blood in $\mathrm{T} / n 1^{\mathrm{fl} / \mathrm{fl}} \mathrm{Cre}^{+}$and $\mathrm{T} / n 1^{\mathrm{fl} / \mathrm{fl}} \mathrm{Cre}^{2}$ mice at 8-10 wk of age was determined by a guaiac-based hemoccult assay. (D) Peripheral red blood cell counts from 10-wk-old $\mathrm{T} / n 7^{\mathrm{fl} / \mathrm{fl}} \mathrm{Cre}^{+}$and $\mathrm{T} / \mathrm{n} 7^{\mathrm{fl} / \mathrm{fl}} \mathrm{Cre}^{2}$ littermates. 
red blood cell counts and hemoglobin concentration (Fig. 2 D and Table S1).

The hemostatic defects observed in $T \ln 1^{\mathrm{f} / \mathrm{fl}} \mathrm{Cre}^{+}$mice are at least as severe as those observed in $\beta 3$ integrin null mice (17). In our hands, $22.9 \%$ fewer $\beta 3^{-/-}$than $\beta 3^{+/+}$offspring from $\beta 3^{+/-}$by $\beta 3^{+/-}$matings survived to $3 \mathrm{wk}$ of age, a smaller reduction in survival compared with $T \ln 1^{\mathrm{fl} / \mathrm{fl}} \mathrm{Cre}^{+}$ mice (45\% fewer $T \ln 1^{\mathrm{f} / \mathrm{fl}} \mathrm{Cre}^{+}$than $T \ln 1^{\mathrm{f} / \mathrm{fl}} \mathrm{Cre}^{-}$). However, because the $T \ln 1^{\mathrm{f} / \mathrm{fl}}$ and $\beta 3$ null mice were both on mixed genetic backgrounds (C57BL/6-Sv129), it is not possible to make definitive statements regarding the relative hemostatic impairment in these mice.

\section{Platelet talin is required for thrombus formation}

Thrombus formation in mice with talin-deficient platelets was examined in vivo by ferric chloride-induced injury of the common carotid artery. Complete occlusion of the carotid arteries of $T \ln 1^{\mathrm{f} / \mathrm{fl}} \mathrm{Cre}^{-}$mice occurred $7.0 \pm 0.9 \mathrm{~min}$ after injury, whereas none of the $T \ln 1^{\mathrm{f} / \mathrm{fl}} \mathrm{Cre}^{+}$mice tested showed reduced flow during the 20-min assay (Fig. 3). Histological examination of the carotid arteries of these animals after the thrombosis experiment indicated a similar extent of ferric chloride-induced vessel injury in $T \ln 1^{\mathrm{f} / \mathrm{fl}} \mathrm{Cre}^{+}$and $T \ln 1^{\mathrm{f} / \mathrm{fl}} \mathrm{Cre}^{-}$ mice (Fig. S2, available at http://www.jem.org/cgi/content/ full/jem.20071800/DC1). Collectively, our results show that deletion of talin1 in platelets leads to markedly impaired hemostasis and thrombus formation in vivo.

$\alpha 2 \beta 1$ integrin-mediated adhesion of platelets to exposed subendothelial collagen after vascular trauma is thought to be a key step in hemostasis. To examine the ability of $T \ln 1^{\mathrm{A} / \mathrm{fl}} \mathrm{Cre}^{+}$ platelets to adhere to collagen under physiological conditions, we measured platelet adhesion and thrombus formation to
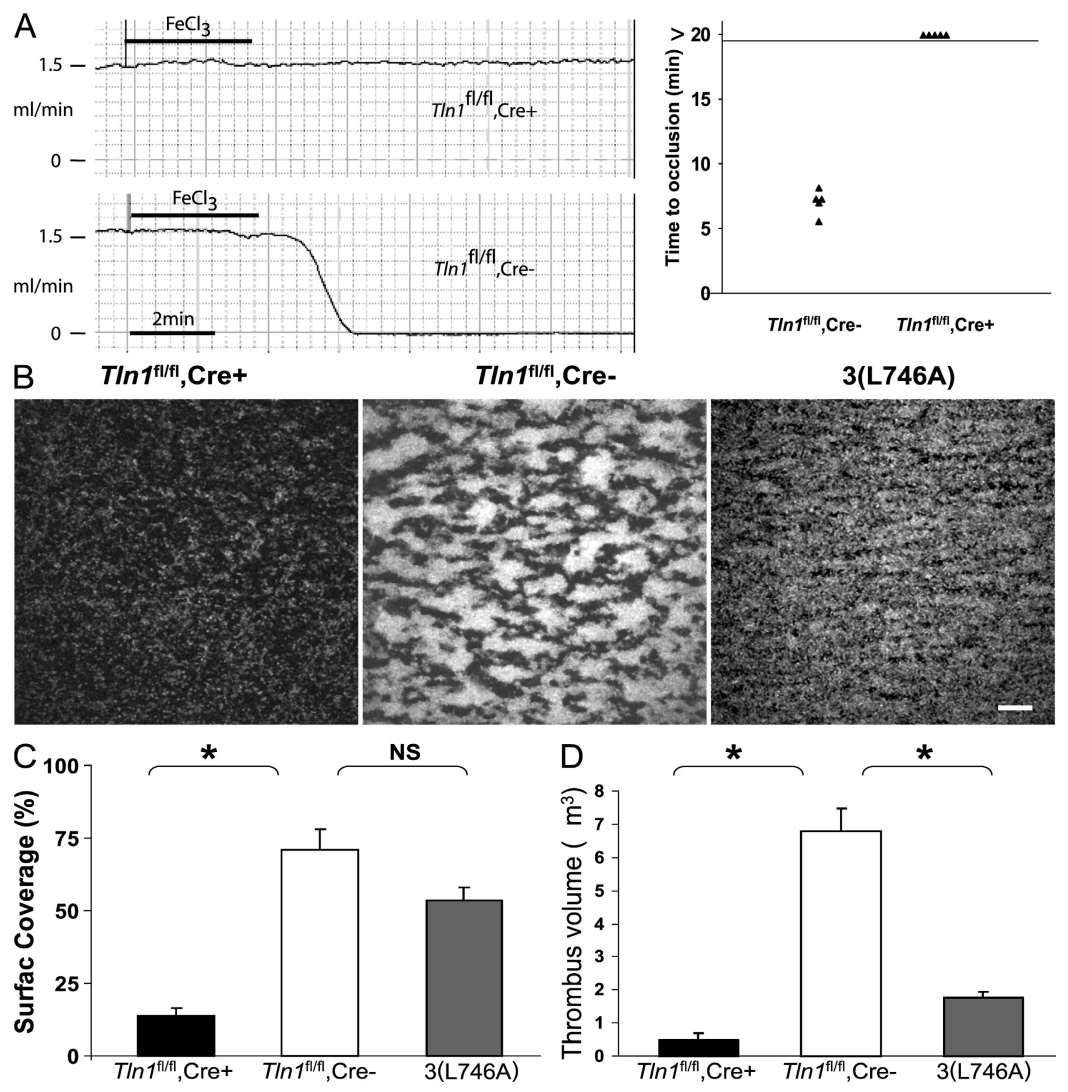

Figure 3. Impaired thrombus formation in $\mathrm{T} \ln 1^{\mathrm{fl} / \mathrm{fl}} \mathrm{Cre}^{+}$mice in vivo and ex vivo. (A) Time to occlusion of the carotid artery was determined with a Doppler flow probe after a 3-min application of 10\% ferric chloride. The experiment was stopped 20 min after injury in all animals. (B) Adhesion of T/n $7^{f / / f l}$ $\mathrm{Cre}^{+}, \mathrm{T} \ln 7^{\mathrm{fl} / \mathrm{fl}} \mathrm{Cre}^{2}$, and b3(L476A) platelets to collagen and subsequent thrombus formation in flowing blood were analyzed by epifluorescence and confocal microscopy at a shear rate of 1,500 s21. Heparinized whole blood containing $10 \mathrm{mM}$ mepacrine to render platelets fluorescent was perfused over glass coated with fibrillar type I collagen for $2 \mathrm{~min}$. $T / \mathrm{n}^{f^{f l / f l}} \mathrm{Cre}^{2}$ platelets adhere to the collagen-coated surface and form thrombi (larger aggregates of bright fluorescence). In contrast, $T / n 7^{\mathrm{fl} / \mathrm{fl}} \mathrm{Cre}^{+}$platelets form only transient contacts resulting in sparse coverage of platelets on the surface. b3(L746A) platelets form a monolayer that cover much of the surface but do not form thrombi, as seen by the lack of highly fluorescent aggregates that form with $T / n f^{f / f f l}$ $\mathrm{Cre}^{2}$ platelets. Images shown are single frames from a real-time recording (Video S1). Bar, $20 \mathrm{~mm}$. (C) Percent of the collagen-coated surface covered with platelets was calculated as the number of fluorescent pixels (due to adhesion of fluorescently labeled platelets) divided by the total number of pixels (representing the total surface). ${ }^{*}, P<0.0005$; NS, not significant. (D) Quantification of the volume of the thrombi formed on the collagen-coated surface after perfusion for 2 min with blood from $\mathrm{Tln} 7^{\mathrm{fl} / \mathrm{fl}} \mathrm{Cre}^{+}, \mathrm{Tln} 7^{\mathrm{fl} / \mathrm{fl}} \mathrm{Cre}^{2}$, and b3(L746A) mice. Confocal serial Z-section reconstructions of the platelet thrombi were used to calculate the thrombi volume as described previously (reference 32). ${ }^{*}, \mathrm{P}<0.0005$. 
collagen in flowing blood. Platelets from $T \ln 1^{\mathrm{f} / \mathrm{fl}} \mathrm{Cre}^{-}$mice stably adhered to the collagen-coated surface and subsequently formed platelet-rich thrombi visible as highly fluorescent aggregates (Fig. $3 \mathrm{~B}$, middle). In contrast, $T \ln 1^{\mathrm{f} / \mathrm{fl}} \mathrm{Cre}^{+}$ platelets formed only transient contacts with the collagencoated surface and did not form thrombi (Fig. 3 and Video S1, which is available at http://www.jem.org/cgi/content/ full/jem.20071800/DC1). Interestingly, platelets from $\beta 3(\mathrm{~L} 746 \mathrm{~A})$ mice, in which $\beta 3$ integrin-talin interactions are selectively disrupted (18), formed stable adhesions to collagen indicated by the platelet monolayer shown in Fig. $3 \mathrm{~B}$ and quantified in Fig. 3 C. Nevertheless, the $\beta 3$ (L746A) platelets failed to undergo the integrin $\alpha \operatorname{IIb} \beta 3$-mediated plateletplatelet interactions required for thrombus formation (Fig. 3, $\mathrm{B}$ and D). Thus, lack of platelet talin impairs $\alpha 2 \beta 1$ integrindependent adhesion to collagen in flow and integrin $\alpha \operatorname{IIb} \beta 3-$ dependent platelet thrombus formation.

\section{Platelet talin is required for integrin-mediated platelet adhesion to collagen and platelet aggregation}

We examined platelet adhesion and aggregation in vitro to directly assess the effects of talin deficiency on these integrindependent processes. In static adhesion assays, the talin-deficient platelets showed a marked defect in adhesion to soluble type I collagen (Fig. S1 A, available at http://www.jem.org/ cgi/content/full/jem.20071800/DC1). Furthermore, like $\beta 3(\mathrm{~L} 746 \mathrm{~A})$ platelets (18), talin-deficient platelets manifested profoundly impaired aggregation in response to stimulation with ADP or PAR 4 peptide (Fig. S1 B). Thus, the talin-deficient platelets manifest virtual absence of platelet functions mediated by both $\alpha 2 \beta 1$ and $\alpha \operatorname{IIb} \beta 3$ integrins, thus accounting for their profound hemostatic defect.

\section{Talin is required for activation of platelet $\alpha 2 \beta 1$ and $\alpha$ llb $\beta 3$ integrins}

Agonist-induced increase in integrin $\alpha \operatorname{IIb} \beta 3$ affinity (activation) is required for platelet aggregation (19). Indeed, $\beta 3$ (L746A) mice, in which $\alpha \operatorname{IIb} \beta 3$-talin interactions are disrupted, have impaired $\alpha \operatorname{IIb} \beta 3$ integrin activation and platelet aggregation (18). To test the requirement of talin for the activation of $\alpha \mathrm{IIb} \beta 3$, we measured binding of FITC-labeled fibrinogen to the surface of washed $T \ln 1^{\mathrm{f} / \mathrm{fl}} \mathrm{Cre}^{+}$and $T \ln 1^{\mathrm{f} / \mathrm{fl}} \mathrm{Cre}^{-}$platelets by flow cytometry. Stimulation of $T \ln 1^{\mathrm{f} / \mathrm{fl}} \mathrm{Cre}^{-}$platelets with a combination of ADP/epinephrine (100 $\mu \mathrm{M}$ each) or PAR 4 peptide $(1 \mathrm{mM})$ led to an increase in the amount of bound fibrinogen. In contrast, the amount of agonist-induced fibrinogen binding was greatly reduced in $T \ln 1^{\mathrm{f} / \mathrm{fl}} \mathrm{Cre}^{+}$platelets (Fig. $4 \mathrm{~A}$ and Fig. S3, which is available at http://www .jem.org/cgi/content/full/jem.20071800/DC1). In the presence of $0.5 \mathrm{mM} \mathrm{MnCl} 2$, however, $T \ln 1^{\mathrm{f} / \mathrm{fl}} \mathrm{Cre}^{+}$and $T \ln 1^{\mathrm{f} / \mathrm{fl}}$ $\mathrm{Cre}^{-}$platelets bound similar amounts of fibrinogen, indicating that the $\alpha \mathrm{IIb} \beta 3$ present on $T \ln 1^{\mathrm{f} / \mathrm{fl}} \mathrm{Cre}^{+}$platelets is capable of binding fibrinogen if activated exogenously (Fig. $4 \mathrm{~B}$ and Fig. S3). Thus, with regards to $\alpha \operatorname{IIb} \beta 3$ activation, platelet talin deficiency phenocopies the $\beta 3$ (L746A) mutation in which the $\beta 3$ integrin-talin interaction is disrupted. Collectively,
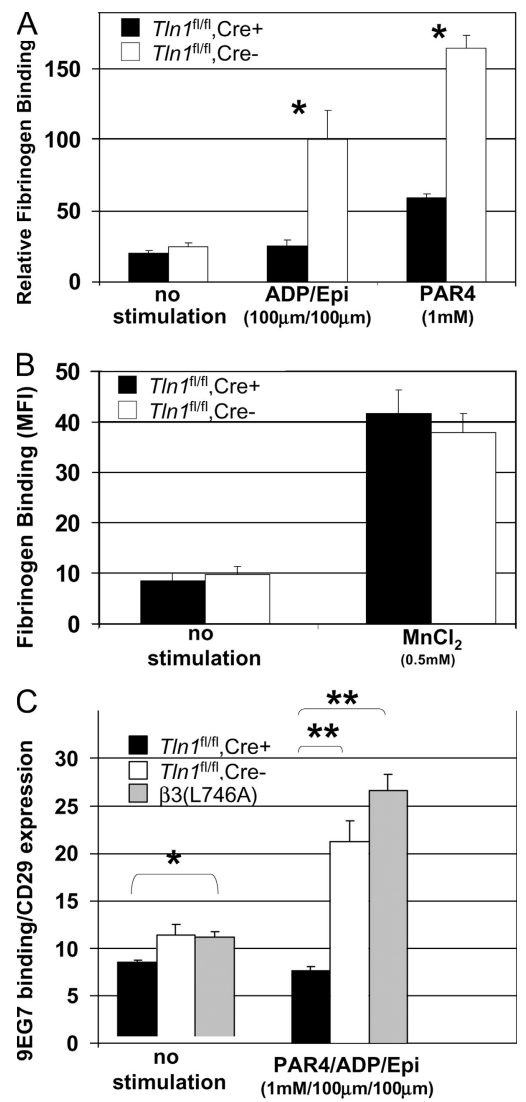

Figure 4. Impaired agonist-induced activation of b3 and b1 integrins in $\mathrm{Tln} 1^{\mathrm{fl} / \mathrm{fl}} \mathrm{Cre}^{+}$platelets. (A) The amount of FITC-labeled fibrinogen bound to platelets from $\mathrm{Tln} 7^{\mathrm{fl} / \mathrm{fl}} \mathrm{Cre}^{+}$or $\mathrm{T} / n 7^{\mathrm{fl} / \mathrm{fl}} \mathrm{Cre}^{2}$ mice was measured by flow cytometry and expressed as the amount of fibrinogen bound to platelets in each group relative to the amount of fibrinogen bound to platelets in the presence of $0.5 \mathrm{mM} \mathrm{MnCl}{ } \cdot{ }^{*}, \mathrm{P}<0.001$. (B) Fibrinogen binding to $T / n 7^{\mathrm{fl} / \mathrm{fl}} \mathrm{Cre}^{+}$and $T / n 7^{\mathrm{ft} / \mathrm{fl}} \mathrm{Cre}^{2}$ platelets was similar in the presence of $0.5 \mathrm{mM} \mathrm{MnCl}_{2}$. (C) Activation of b1 integrin in $\mathrm{T} / n 7^{\mathrm{fl} / \mathrm{fl}} \mathrm{Cre}^{+}, \mathrm{T} \ln 7^{\mathrm{fl} / \mathrm{fl}}$ $\mathrm{Cre}^{2}$, and b3(L746A) platelets after stimulation with $1 \mathrm{mM}$ PAR4, $100 \mathrm{~mm}$ $\mathrm{ADP}$, and $100 \mathrm{mM}$ epinephrine was measured by binding of the conformation-sensitive antibody 9EG7 and expressed relative to total b1 integrin surface expression measured by the conformation-insensitive antibody HMb1-1. ${ }^{*}, \mathrm{P}<0.05 ;{ }^{*}, \mathrm{P}<0.0005$.

these data firmly establish talin as a critical regulator of $\alpha \operatorname{IIb} \beta 3$ integrin activation in vivo.

The impaired adhesion of $T \ln 1^{\mathrm{f} / \mathrm{fl}} \mathrm{Cre}^{+}$platelets to collagen noted above suggests that $\alpha 2 \beta 1$ integrin activation may also be impaired in $T \ln 1^{\mathrm{A} / \mathrm{fl}} \mathrm{Cre}^{+}$platelets. To examine the activation of $\beta 1$ integrins in $T \ln 1^{\mathrm{f} / \mathrm{fl}} \mathrm{Cre}^{+}$platelets, we measured the binding of the conformation-sensitive $\beta 1$ integrin antibody 9EG7 to agonist-stimulated platelets. $T \ln 1^{\mathrm{f} / \mathrm{fl}} \mathrm{Cre}^{-}$ platelets bound significantly more 9EG7 upon stimulation. This response was largely ablated in platelets from $T \ln 1^{\mathrm{f} / \mathrm{fl}}$ $\mathrm{Cre}^{+}$mice (Fig. 4 C). These results show that talin expression is required for agonist-induced activation of both $\alpha \operatorname{IIb} \beta 3$ and $\alpha 2 \beta 1$ integrins in platelets. In addition, these data suggest that impaired activation of $\alpha 2 \beta 1$ integrins contributes to the spontaneous bleeding observed in $T \ln 1^{\mathrm{A} / \mathrm{fl}} \mathrm{Cre}^{+}$mice. 
Thus, the principle that talin is required for activation of $\beta 1$ and $\beta 3$ integrins, which was suggested by in vitro studies (20), applies in vivo. Furthermore, the central role of talin in integrin function in invertebrates $(11,12,21)$ extends to vertebrates. A $\beta 3(\mathrm{~L} 746 \mathrm{~A})$ mutation that selectively disrupts the ability of $\beta 3$ integrin to bind talin leads to impaired agonistinduced activation of platelet $\alpha \operatorname{IIb} \beta 3$ (18). Together with the present finding of impaired agonist-induced activation of $\alpha \mathrm{IIb} \beta 3$ in talin-deficient platelets, these data show that talin binding to integrin $\beta$ cytoplasmic domains is a final common step in integrin activation in vivo, and that disruption of this interaction has a profound impact on integrin-dependent adhesive functions in mammals.

Talin-deficient platelets are nearly completely deficient in hemostatic function. It is noteworthy that the pathological bleeding observed in $T \ln 1^{\mathrm{A} / \mathrm{fl}} \mathrm{Cre}^{+}$mice is absent in $\beta 3(\mathrm{~L} 746 \mathrm{~A})$ mice despite having comparable impairments in $\alpha \operatorname{IIb} \beta 3$ activation and platelet aggregation (18). One obvious explanation for this more severe phenotype in the platelet talin-deficient animals is the impairment in the activation and function of platelet $\beta 1$ integrins. Furthermore, in Drosophila, talin deletion results in marked weakening of the connections of integrins with the actin cytoskeleton; hence, a defect in the connection of $\beta 1$ and $\beta 3$ integrins to the actin cytoskeleton may also contribute to the severe phenotype observed. Deletion of platelet $\beta 1$ integrins or point mutations that would disrupt $\beta 1$-talin interactions can result in defects in platelet function and in hemostasis $(4,22)$. Given the hemostatic defects that result from lack of platelet $\beta 3$ or $\beta 1$ integrins, and our finding that platelet integrin function is virtually completely dependent on talin, it is likely that the hemostatic defect in $T \ln 1^{\mathrm{A} / \mathrm{fl}} \mathrm{Cre}^{+}$mice is ascribable largely to the lack of integrin function.

\section{Morphology and surface receptor expression is normal in talin-deficient platelets}

To examine the effect of deleting talin on platelet structure, we examined $T \ln 1^{\mathrm{f} / \mathrm{fl}} \mathrm{Cre}^{+}$and $T \ln 1^{\mathrm{f} / \mathrm{fl}} \mathrm{Cre}^{-}$platelet morphology by electron microscopy. Platelet shape, $\alpha$ granules, mitochondria, open canalicular system, and microtubule coils appeared similar in $T \ln 1^{\mathrm{A} / \mathrm{fl}} \mathrm{Cre}^{+}$and $T \ln 1^{\mathrm{A} / \mathrm{fl}} \mathrm{Cre}^{-}$platelets (Fig. 5 A). $T \ln 1^{\mathrm{A} / \mathrm{fl}} \mathrm{Cre}^{+}$mice had slightly larger platelets than $T \ln 1^{\mathrm{A} / \mathrm{Al}} \mathrm{Cre}^{-}$mice as judged by flow cytometry (forward scatter, $13.9 \pm 0.2$ vs. $15.3 \pm 0.4$ arbitrary units, $T \ln 1^{\mathrm{A} / \mathrm{f}} \mathrm{Cre}^{-}$ vs. $\left.T \ln 1^{\mathrm{H} / \mathrm{fl}} \mathrm{Cre}^{+}, \mathrm{P}<0.005\right)$ and by measurement of the area of at least 140 randomly selected electron microscopic platelet profiles $\left(0.67 \pm 0.03 \mu \mathrm{m}^{2}\right.$ vs. $0.97 \pm 0.4 \mu \mathrm{m}^{2}$, $T \ln 1^{\mathrm{A} / \mathrm{A}}$ $\mathrm{Cre}^{-}$vs. $\left.T \ln 1^{\mathrm{H} / \mathrm{fl}} \mathrm{Cre}^{+}, \mathrm{P}<0.005\right)$. As noted above, the $T \ln 1^{\mathrm{A} / \mathrm{Al}}$ $\mathrm{Cre}^{+}$mice have active gastrointestinal bleeding, suggesting that the slightly increased platelet size could be due to an increased proportion of circulating young platelets. In contrast to $\beta 3$ integrin null platelets (17), talin-deficient platelets had normal fibrinogen content, suggesting that talin-dependent activation of $\alpha \mathrm{IIb} \beta 3$ in mature megakaryocytes is not required for fibrinogen uptake (Fig. 5 B). In addition, the surface expression of several adhesion receptors, as measured by flow

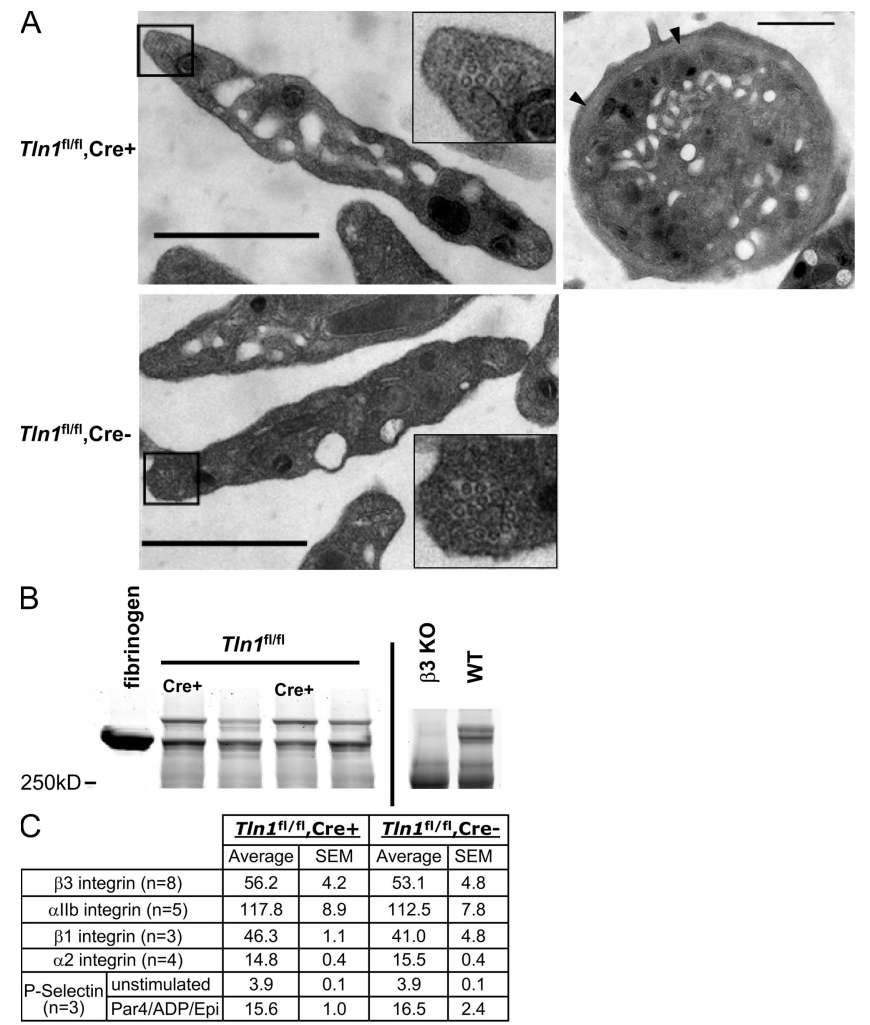

Figure 5. Platelets from $\operatorname{Tln} 1^{\mathrm{fl} / \mathrm{fl}} \mathrm{Cre}^{+}$mice are structurally normal and express normal levels of surface receptors. (A) Electron micrographs showing normal structural features of $\mathrm{Tln}^{\mathrm{ffl} / \mathrm{fl}} \mathrm{Cre}^{+}$platelets. Platelets from $\operatorname{Tln} 7^{\mathrm{fl} / \mathrm{fl}} \mathrm{Cre}^{+}$(top left) and $\operatorname{Tln} 7^{\mathrm{fl} / \mathrm{fl}} \mathrm{Cre}^{2}$ (bottom left) mice both display a discoid shape characteristic of resting platelets and similar granular contents. Insets show microtubule coils in platelets from both $T \ln 7^{\mathrm{fl} / \mathrm{fl}}$ $\mathrm{Cre}^{+}$and $\mathrm{TIn} 7^{\mathrm{fl} / \mathrm{fl}} \mathrm{Cre}^{2}$ mice. Equatorial section of a $\mathrm{TIn} 7^{\mathrm{fl|} / \mathrm{fl}} \mathrm{Cre}^{+}$platelet (top right) shows circumferential microtubule coil (arrow heads). Bars, $1 \mathrm{~mm}$. (B) Platelet fibrinogen content was determined by Coomassie blue staining of platelet lysates separated by SDS-PAGE. $5 \mathrm{mg}$ of purified human fibrinogen served as a marker for the prominent protein band corresponding to fibrinogen in the platelet lysate samples. Consistent with previous reports (reference 17), fibrinogen content is reduced in platelets from b3 integrin null mice. (C) Surface expression of integrin allb, a2, b1, b3, and P-selectin was measured by flow cytometry. For P-selectin expression, platelets were incubated with or without PAR4/ADP/epinephrine $(1 \mathrm{~mm} / 100 \mathrm{mM} /$ $100 \mathrm{mM}$ ) for $5 \mathrm{~min}$ before the addition of an FITC-conjugated

P-selectin antibody.

cytometry, was not significantly different in $\operatorname{Tln} 1^{\mathrm{A} / \mathrm{fl}} \mathrm{Cre}^{+}$and $T \ln 1^{\mathrm{A} / \mathrm{Al}} \mathrm{Cre}^{-}$platelets (Fig. 5 C). Of particular importance, the quantity of surface P-selectin was similar on both resting and stimulated $T \ln 1^{\mathrm{A} / \mathrm{fl}} \mathrm{Cre}^{+}$and $T \ln 1^{\mathrm{A} / \mathrm{fl}} \mathrm{Cre}^{-}$platelets, confirming the presence of platelet $\alpha$ granules in the absence of talin. Furthermore, both platelet genotypes exhibited a similar fourfold increase in $\mathrm{P}$-selectin surface expression in response to ADP/epinephrine/PAR4 peptide stimulation, confirming that the mutant platelets were capable of responding to platelet agonists. Collectively, these data demonstrate that talin is dispensable for the formation of platelets that can respond to platelet agonists and manifest a normal complement of granule 
constituents and adhesion receptors. Thus, the observed adhesion defects in $T \ln 1^{\mathrm{A} / \mathrm{fl}} \mathrm{Cre}^{+}$mice are ascribable to loss of talinmediated integrin functions and not a general disruption of platelet structure and function.

Platelet shape has been proposed to depend on the cortical actin cytoskeleton. Platelet filamin and spectrin play important roles in this cortical cytoskeleton (23), whereas talin is cytoplasmic in resting platelets and only recruited to the cortical cytoskeleton after platelet activation $(24,25)$. The normal shape of the talin-deficient platelets provides direct proof that platelet talin makes little if any contribution to the integrity of the cortical cytoskeleton in resting platelets. Furthermore, the talin-deficient platelets contained normalappearing $\alpha$ granules and comparable contents of fibrinogen and P-selectin to littermate control mice. P-selectin is synthesized by megakaryocytes, whereas the bulk of platelet fibrinogen is taken up from the plasma; that uptake depends on integrin $\alpha \operatorname{IIb} \beta 3$ (26). The ability of talin-deficient megakaryocytes to package fibrinogen into $\alpha$ granules is noteworthy in light of the defect in activation of integrin $\alpha \operatorname{IIb} \beta 3$ in these platelets. It is possible that residual talin in early megakaryocytes may permit normal fibrinogen uptake; however, we have also observed normal platelet fibrinogen in the $\beta 3(\mathrm{~L} 746 \mathrm{~A})$ platelets that have a similar defect in $\alpha \operatorname{IIb} \beta 3$ integrin activation (unpublished data), and human platelets with a $\beta 3(\mathrm{~S} 752 \mathrm{P})$ mutation also contain normal quantities of fibrinogen in spite of manifesting defective $\alpha \mathrm{IIb} \beta 3$ activation (27). Thus, even though integrin $\alpha \operatorname{IIb} \beta 3$ ligand binding function is required for normal fibrinogen uptake in megakaryocytes (26), activation of the integrin is not needed. In addition, talin-deficient platelets increased their surface expression of $\mathrm{P}$-selectin in response to platelet agonists, indicating that the platelets could respond to the agonists, a conclusion supported by the normal shape change in the platelet aggregation tracings. Similarly, the increased surface P-selectin suggests that $\alpha$ granule secretion does not depend on talin; notably, this process is PIP2 dependent (28), and talin can recruit and regulate one isoform of PI5 kinase (29), a rate-limiting step in PIP2 synthesis. In summary, the talindeficient platelets exhibit normal morphology and respond to platelet agonists.

Here, we have shown that platelet talin is essential for platelet-dependent hemostasis because it is required for the function and activation of $\beta 1$ and $\alpha \operatorname{IIb} \beta 3$ integrins. Despite $\operatorname{Tln} 1^{\mathrm{f} / \mathrm{Al}} \mathrm{Cre}^{+}$mice having normal platelet counts, these animals exhibited both lethal spontaneous bleeding and resistance to induced thrombosis. These in vivo findings were ascribable to profound defects in the function of multiple platelet integrins, as platelets from $\operatorname{Tn} 1^{\mathrm{H} / \mathrm{fl}} \mathrm{Cre}^{+}$mice failed to adhere to collagen or to form platelet-rich thrombi ex vivo. In vitro studies documented the profound impairment of integrin-mediated adhesion and platelet aggregation in talin1deficient platelets and showed that these platelets were deficient in the agonist-induced activation of both $\alpha 2 \beta 1$ and $\alpha \mathrm{IIb} \beta 3$ integrins, despite maintaining the capacity to respond to the agonists as indicated by surface display of P-selectin.
Thus, talin is necessary for the activation of $\alpha 2 \beta 1$ and $\alpha \operatorname{IIb} \beta 3$ integrins in vivo, and platelet talin is absolutely required for hemostasis because it is necessary for the adhesive functions of these integrins.

\section{MATERIALS AND METHODS}

Generation of mice. Conditional talin 1 knockout mice were generated by introducing loxP sites flanking coding exons 1-4 of the $T \ln 1$ gene by gene targeting. Targeting of the $T \ln 1$ locus was confirmed by Southern blot of EcoR1-digested genomic DNA hybridized with a 5' cDNA probe. Mice were genotyped by PCR using the following primers indicated in Fig. 1 A: primer a: $5^{\prime}$-aagcaggaacaaaagtaggtctcc- $3^{\prime}$ and primer b: $5^{\prime}$-gcatcgtcttcaccacattcc- $3^{\prime}$. Mice homozygous for the $T \ln 1$ floxed allele $\left(\operatorname{Tln} 1^{\mathrm{A} / \mathrm{fl}}\right)$ on a mixed C57BL/6-Sv129 genetic background were crossed with PF4-Cre (Cre ${ }^{+}$) mice on a C57BL/ 6 background (15). To obtain mice with talin1-deficient platelets, $T \ln 1^{\mathrm{f} / \mathrm{fl}} \mathrm{Cre}^{+}$males were bred with $T \ln 1^{\mathrm{f} / \mathrm{fl}} \mathrm{Cre}^{-}$females. In all experiments, $T \ln 1^{\mathrm{f} / \mathrm{fl}} \mathrm{Cre}^{+}$mice were compared with $T \ln 1^{\mathrm{f} / \mathrm{fl}} \mathrm{Cre}^{-}$sexmatched littermates. The generation of $\beta 3(\mathrm{~L} 746 \mathrm{~A})$ mice has been recently described (18). Mice were housed in the University of California, San Diego, animal facility, and experiments were approved by the university's Institutional Animal Care and Use Committee.

SDS-PAGE. For examination of platelet talin protein content, washed platelets were lysed by adding 1 vol of $2 \mathrm{X}$ modified RIPA buffer $(300 \mathrm{mM}$ $\mathrm{NaCl}, 100$ mM Tris, pH 7.4, 0.2\% SDS, 2\% Triton X-100, 2\% sodium deoxycholate, 2 mM PMSF, 2 mM NaVO4, 2 mM NaF, 2 mM EDTA, and complete protease inhibitor; Roche), and samples were clarified by centrifugation at $13,000 \mathrm{~g}$ for $10 \mathrm{~min}$ at $4^{\circ} \mathrm{C}$. Laemmli buffer containing $10 \mathrm{mM}$ DTT was added to $10 \mu \mathrm{g}$ of protein lysates, and samples were boiled for 5 min before being separated on 6\% Tris-glycine gels (Invitrogen) and stained with Coomassie blue. For analysis of platelet fibrinogen content, platelets were lysed in Laemmli buffer in the absence of any reducing agent and separated on a $6 \%$ Tris-glycine gel. Fibrinogen was identified as a Coomassie blue-stained band migrating with an apparent molecular mass of 340,000.

Immunofluorescence. After lysing red blood cells with RBC lysis buffer (155 mM NH4Cl, $10 \mathrm{mM} \mathrm{KHCO}_{3}$, and $0.1 \mathrm{mM}$ EDTA) bone marrow cells from the femurs of 6-9-wk-old mice were fixed in 3.7\% formaldehyde/PBS and applied to fibrinogen-coated $(100 \mu \mathrm{g} / \mathrm{ml})$ glass slides by Cytospin preparation (Thermo Fisher Scientific). Cells were permeabilized with $0.1 \%$ Triton $\mathrm{X}-100 / \mathrm{PBS}$ containing 5\% BSA for $1 \mathrm{~h}$ at room temperature and incubated with talin antibody $8 \mathrm{~d} 4$ (1:50 dilution; Sigma-Aldrich) overnight at $4{ }^{\circ} \mathrm{C}$. After washing with PBS, cells were incubated with $2.5 \mu \mathrm{g} / \mathrm{ml}$ FITC-conjugated anti-CD 41 (BD Biosciences) and $5 \mu \mathrm{g} / \mathrm{ml}$ Alexa-568 goat anti-mouse IgG for $2 \mathrm{~h}$ at room temperature. After washing, slides were mounted with coverslips using Vectashield anti-fade media (Vector Laboratories) and observed on a Leica DM LS fluorescence microscope. Images were captured with a spot color digital camera (National Instruments) using manual exposure settings that were identical for $T \ln 1^{\mathrm{A} / \mathrm{fl}} \mathrm{Cre}^{+}$and $T \ln 1^{\mathrm{A} / \mathrm{f}} \mathrm{Cre}^{-}$samples.

Hemostasis assays. The presence of fecal blood was detected with a guaiac-based hemoccult detection assay (Helena Laboratories) on freshly obtained stool samples.

Tail bleeding assays were performed by resecting $1 \mathrm{~mm}$ of the tail, followed by immersion in $37^{\circ} \mathrm{C}$ isotonic saline as described previously (17). All experiments were terminated at $10 \mathrm{~min}$ by cauterizing the tail.

Platelet isolation and functional assays. Washed platelets were obtained as described previously (30). Soluble fibrinogen binding was measured by incubating platelets for $20 \mathrm{~min}$ with $150 \mu \mathrm{g} / \mathrm{ml}$ FITC-labeled fibrinogen, followed by fixation with $1 \%$ formaldehyde for $10 \mathrm{~min}$ at room temperature. Specific fibrinogen binding was determined by subtracting the amount of fibrinogen bound in the presence of $5 \mathrm{mM}$ EDTA. Bound fibrinogen 
was detected with a FACScan flow cytometer (Becton Dickinson). $\beta 1$ integrin activation was measured by the binding of an FITC-labeled confirmation-sensitive $\beta 1$ integrin antibody 9EG7 (BD Biosciences), or the confirmation-insensitive PE-conjugated $\beta 1$ antibody HM $\beta 1-1$ (BD Biosciences). Washed platelets were incubated with or without agonists for $10 \mathrm{~min}$ at room temperature, followed by the addition of $3 \mu \mathrm{g} / \mathrm{ml}$ of either 9EG7 or HM $31-1$ for 20 min and detected by flow cytometry. Similarly, surface expression of P-selectin was measured by the binding of FITC-anti-P-selectin (BD Biosciences) following the same protocol as described above for measuring $\beta 1$ integrin activation. Surface expression of $\beta 3, \alpha I I b$, and $\alpha 2$ integrins were measured by flow cytometry with the following antibodies: FITC-anti-CD61, FITC-anti-CD41 (BD Biosciences), and PE-anti- $\alpha 2$ integrin (eBioscience).

For analysis of static adhesion of platelets to collagen, 96-well plates (Immulon HB2; Dynex Technologies) were coated with $2 \mu \mathrm{g}$ of acid-soluble type I collagen from rat tail (Sigma-Aldrich) in $100 \mu \mathrm{l}$ PBS overnight at $4^{\circ} \mathrm{C}$. After two washes with PBS and blocking with 5\% BSA/PBS for $2 \mathrm{~h}$ at room temperature, $5 \times 10^{6}$ washed platelets suspended in platelet incubation buffer were added to each well and allowed to adhere for $1 \mathrm{~h}$ at room temperature. Wells were then washed three times with platelet incubation buffer, and adherent platelets were quantified by acid-phosphatase assay (18). Percent platelet adhesion was calculated as the number of adherent platelets relative to the number of platelets in wells that were not washed (total platelets per well). Platelet aggregation was performed as described previously (18) using plateletrich plasma (PRP) diluted to a platelet concentration of $3 \times 10^{8}$ platelets $/ \mathrm{ml}$ with platelet-poor plasma.

Ex vivo adhesion to collagen. Adhesion and thrombus formation in flowing blood was performed and analyzed as described previously $(31,32)$.

Transmission electron microscopy. Blood was drawn by cardiac puncture into $0.1 \mathrm{vol}$ of $0.13 \mathrm{M}$ sodium citrate. After adding 1 vol modified Tyrode's buffer $\left(140 \mathrm{mM} \mathrm{NaCl}, 2.7 \mathrm{mM} \mathrm{KCl}, 0.4 \mathrm{mM} \mathrm{NaH}_{2} \mathrm{PO}_{4}, 10 \mathrm{mM} \mathrm{NaHCO}\right.$, $5 \mathrm{mM}$ dextrose, and $10 \mathrm{mM}$ Hepes) samples were centrifuged for $5 \mathrm{~min}$ at $200 \mathrm{~g}$ at room temperature to obtain PRP. The PRP was incubated for $30 \mathrm{~min}$ at $37^{\circ} \mathrm{C}$ before fixing by the addition of $1 \mathrm{vol}$ of $2 \mathrm{X}$ fixative $(3 \%$ gluteraldehyde and $6 \%$ paraformaldehyde in $0.2 \mathrm{M}$ cacodylate buffer plus $10 \%$ sucrose, $\mathrm{pH} 7.4$ ) and incubated for $15 \mathrm{~min}$ at room temperature. Platelets were centrifuged at $700 \mathrm{~g}$ for $5 \mathrm{~min}$ and resuspended and stored overnight in $1 \mathrm{X}$ fixative. Samples were processed as described previously (33), and images were obtained with a JEOL 1200 EX II electron microscope.

Ferric chloride-induced thrombosis. Ferric chloride-induced thrombosis was performed as described previously (18) by applying a $1.2 \mathrm{X} 1.2-\mathrm{mm}$ piece of filter paper soaked in $10 \%$ ferric chloride to each side of the common carotid artery of a mouse under isoflurane anesthesia.

Statistics. Statistical analyses of mouse survival and spontaneous death were performed with $\chi^{2}$ and Fisher's exact tests, respectively. The statistical significance of all other data were determined using Student's $t$ test. A p-value of $<0.05$ was considered statistically significant. All error bars represent standard error of the mean.

Online supplemental material. Video S1 shows adhesion of fluorescently labeled platelets to fibrillar type I collagen in flowing blood. Time shown is from the beginning of flow over the collagen-coated surface. Video S1 is available at http://www.jem.org/cgi/content/full/jem.20071800/DC1.

We gratefully acknowledge Timo Meerloo and Dr. Marilyn Farquhar for help with electron microscopy. We are grateful to Dr. Catrin Pritchard for advice in generating mice.

This work was supported by grants from the National Institutes of Health (HL31950 and HL078784), the Cell Migration Consortium, NIH (U54 GM064346), and the Wellcome Trust (077532). B.G. Petrich is a fellow of the American Heart Association.

The authors have no conflicting financial interests.
Submitted: 22 August 2007

Accepted: 7 November 2007

\section{REFERENCES}

1. Ruggeri, Z.M. 2002. Platelets in atherothrombosis. Nat. Med. 8: 1227-1234.

2. Nieswandt, B., C. Brakebusch, W. Bergmeier, V. Schulte, D. Bouvard, R. Mokhtari-Nejad, T. Lindhout, J.W. Heemskerk, H Zirngibl, and R. Fassler. 2001. Glycoprotein VI but not alpha2beta1 integrin is essential for platelet interaction with collagen. EMBO J. 20:2120-2130.

3. Chen, J., T.G. Diacovo, D.G. Grenache, S.A. Santoro, and M.M. Zutter. 2002. The alpha(2) integrin subunit-deficient mouse: a multifaceted phenotype including defects of branching morphogenesis and hemostasis. Am. J. Pathol. 161:337-344.

4. Sarratt, K.L., H. Chen, M.M. Zutter, S.A. Santoro, D.A. Hammer, and M.L. Kahn. 2005. GPVI and alpha2beta1 play independent critical roles during platelet adhesion and aggregate formation to collagen under flow. Blood. 106:1268-1277.

5. Shattil, S.J., and P.J. Newman. 2004. Integrins: dynamic scaffolds for adhesion and signaling in platelets. Blood. 104:1606-1615.

6. Ratnikov, B.I., A.W. Partridge, and M.H. Ginsberg. 2005. Integrin activation by talin. J. Thromb. Haemost. 3:1783-1790.

7. O'Halloran, T., M.C. Beckerle, and K. Burridge. 1985. Identification of talin as a major cytoplasmic protein implicated in platelet activation. Nature. 317:449-451.

8. Calderwood, D.A., R. Zent, R. Grant, D.J. Rees, R.O. Hynes, and M.H. Ginsberg. 1999. The Talin head domain binds to integrin beta subunit cytoplasmic tails and regulates integrin activation. J. Biol. Chem. 274:28071-28074.

9. Borowsky, M.L., and R.O. Hynes. 1998. Layilin, a novel talin-binding transmembrane protein homologous with C-type lectins, is localized in membrane ruffles. J. Cell Biol. 143:429-442.

10. Critchley, D.R. 2004. Cytoskeletal proteins talin and vinculin in integrin-mediated adhesion. Biochem. Soc. Trans. 32:831-836.

11. Brown, N.H., S.L. Gregory, W.L. Rickoll, L.I. Fessler, M. Prout, R.A. White, and J.W. Fristrom. 2002. Talin is essential for integrin function in Drosophila. Dev. Cell. 3:569-579.

12. Tanentzapf, G., and N.H. Brown. 2006. An interaction between integrin and the talin FERM domain mediates integrin activation but not linkage to the cytoskeleton. Nat. Cell Biol. 8:601-606.

13. Monkley, S.J., C.A. Pritchard, and D.R. Critchley. 2001. Analysis of the mammalian talin2 gene TLN2. Biochem. Biophys. Res. Commun. 286:880-885.

14. Monkley, S.J., X.H. Zhou, S.J. Kinston, S.M. Giblett, L. Hemmings, H. Priddle, J.E. Brown, C.A. Pritchard, D.R. Critchley, and R. Fassler. 2000. Disruption of the talin gene arrests mouse development at the gastrulation stage. Dev. Dyn. 219:560-574.

15. Tiedt, R., T. Schomber, H. Hao-Shen, and R.C. Skoda. 2007. Pf4-Cre transgenic mice allow the generation of lineage-restricted gene knockouts for studying megakaryocyte and platelet function in vivo. Blood. 109:1503-1506

16. Tsakiris, D.A., L. Scudder, K. Hodivala-Dilke, R.O. Hynes, and B.S. Coller. 1999. Hemostasis in the mouse (Mus musculus): a review. Thromb. Haemost. 81:177-188.

17. Hodivala-Dilke, K.M., K.P. McHugh, D.A. Tsakiris, H. Rayburn, D. Crowley, M. Ullman-Cullere, F.P. Ross, B.S. Coller, S. Teitelbaum, and R.O. Hynes. 1999. Beta3-integrin-deficient mice are a model for Glanzmann thrombasthenia showing placental defects and reduced survival. J. Clin. Invest. 103:229-238.

18. Petrich, B.G., P. Fogelstrand, A.W. Partridge, N. Yousefi, A.J. Ablooglu, S.J. Shattil, and M.H. Ginsberg. 2007. The antithrombotic potential of selective blockade of talin-dependent integrin alpha IIb beta 3 (platelet GPIIb-IIIa) activation. J. Clin. Invest. 117:2250-2259.

19. Bennett, J.S., and G. Vilaire. 1979. Exposure of platelet fibrinogen receptors by ADP and epinephrine. J. Clin. Invest. 64:1393-1401.

20. Tadokoro, S., S.J. Shattil, K. Eto, V. Tai, R.C. Liddington, J.M. de Pereda, M.H. Ginsberg, and D.A. Calderwood. 2003. Talin binding to integrin beta tails: a final common step in integrin activation. Science. 302:103-106. 
21. Cram, E.J., S.G. Clark, and J.E. Schwarzbauer. 2003. Talin loss-offunction uncovers roles in cell contractility and migration in C. elegans. J. Cell Sci. 116:3871-3878.

22. Chen, H., Z. Zou, K.L. Sarratt, D. Zhou, M. Zhang, E. Sebzda, D.A. Hammer, and M.L. Kahn. 2006. In vivo beta1 integrin function requires phosphorylation-independent regulation by cytoplasmic tyrosines. Genes Dev. 20:927-932.

23. Hartwig, J.H., and M. DeSisto. 1991. The cytoskeleton of the resting human blood platelet: structure of the membrane skeleton and its attachment to actin filaments. J. Cell Biol. 112:407-425.

24. Beckerle, M.C., D.E. Miller, M.E. Bertagnolli, and S.J. Locke. 1989. Activation-dependent redistribution of the adhesion plaque protein, talin, in intact human platelets. J. Cell Biol. 109:3333-3346.

25. Fox, J.E., L. Lipfert, E.A. Clark, C.C. Reynolds, C.D. Austin, and J.S. Brugge. 1993. On the role of the platelet membrane skeleton in mediating signal transduction. Association of GP IIb-IIIa, pp60c-src, pp62c-yes, and the p21ras GTPase-activating protein with the membrane skeleton. J. Biol. Chem. 268:25973-25984.

26. Handagama, P., R.M. Scarborough, M.A. Shuman, and D.F. Bainton. 1993. Endocytosis of fibrinogen into megakaryocyte and platelet alphagranules is mediated by alpha IIb beta 3 (glycoprotein IIb-IIIa). Blood. 82:135-138.

27. Nurden, P., C. Poujol, J. Winckler, R. Combrie, J.P. Caen, and A.T. Nurden. 2002. A Ser752区-Pro substitution in the cytoplasmic domain of beta3 in a Glanzmann thrombasthenia variant fails to prevent inter- actions between the alphaIIbbeta3 integrin and the platelet granule pool of fibrinogen. Br. J. Haematol. 118:1143-1151.

28. Rozenvayn, N., and R. Flaumenhaft. 2001. Phosphatidylinositol 4,5bisphosphate mediates $\mathrm{Ca} 2+$-induced platelet alpha-granule secretion: evidence for type II phosphatidylinositol 5-phosphate 4-kinase function. J. Biol. Chem. 276:22410-22419.

29. Di Paolo, G., L. Pellegrini, K. Letinic, G. Cestra, R. Zoncu, S. Voronov, S. Chang, J. Guo, M.R. Wenk, and P. De Camilli. 2002. Recruitment and regulation of phosphatidylinositol phosphate kinase type 1 gamma by the FERM domain of talin. Nature. 420:85-89.

30. Law, D.A., L. Nannizzi-Alaimo, K. Ministri, P.E. Hughes, J. Forsyth, M. Turner, S.J. Shattil, M.H. Ginsberg, V.L. Tybulewicz, and D.R. Phillips. 1999. Genetic and pharmacological analyses of Syk function in alphaIIbbeta3 signaling in platelets. Blood. 93:2645-2652.

31. Konstantinides, S., J. Ware, P. Marchese, F. Almus-Jacobs, D.J Loskutoff, and Z.M. Ruggeri. 2006. Distinct antithrombotic consequences of platelet glycoprotein Ibalpha and VI deficiency in a mouse model of arterial thrombosis. J. Thromb. Haemost. 4:2014-2021.

32. Savage, B., F. Almus-Jacobs, and Z.M. Ruggeri. 1998. Specific synergy of multiple substrate-receptor interactions in platelet thrombus formation under flow. Cell. 94:657-666.

33. Head, B.P., H.H. Patel, D.M. Roth, F. Murray, J.S. Swaney, I.R. Niesman, M.G. Farquhar, and P.A. Insel. 2006. Microtubules and actin microfilaments regulate lipid raft/caveolae localization of adenylyl cyclase signaling components. J. Biol. Chem. 281:26391-26399. 